
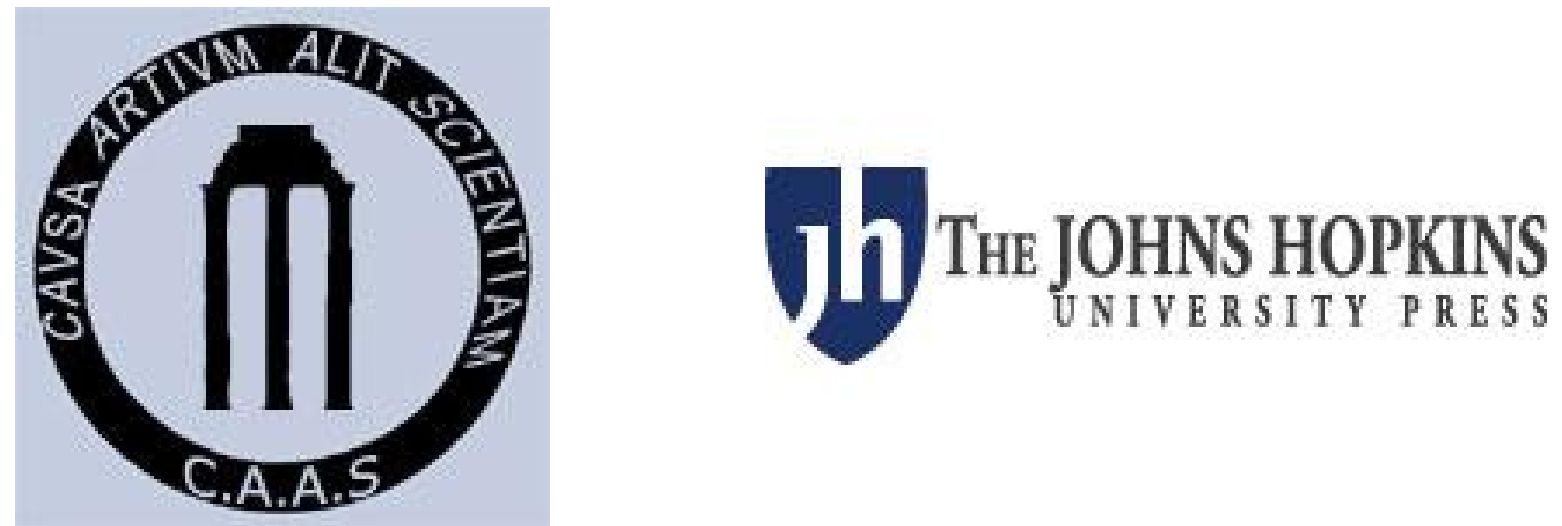

Horace and Catullus: The Case of the Suppressed Precursor in "Odes" 1.22 and 1.32 Author(s): Thomas K. Hubbard

Source: The Classical World, Vol. 94, No. 1 (Autumn, 2000), pp. 25-37

Published by: The Johns Hopkins University Press on behalf of the Classical Association of the Atlantic States

Stable URL: http://www.jstor.org/stable/4352495

Accessed: 08-08-2016 17:33 UTC

Your use of the JSTOR archive indicates your acceptance of the Terms \& Conditions of Use, available at

http://about.jstor.org/terms

JSTOR is a not-for-profit service that helps scholars, researchers, and students discover, use, and build upon a wide range of content in a trusted digital archive. We use information technology and tools to increase productivity and facilitate new forms of scholarship. For more information about JSTOR, please contact support@jstor.org.

Classical Association of the Atlantic States, The Johns Hopkins University Press are collaborating with JSTOR to digitize, preserve and extend access to The Classical World 


\section{HoRaCe AND Catullus: THE CASE OF THE SUPPRESSED PRECURSOR IN ODES 1.22 AND 1.32}

Any reader of Horace's Odes will be struck by the repeated claim that this poet is the first to put Italian themes into Greek forms (most clearly expressed in the retrospective summary of his achievement in C. 3.30.13-14 princeps Aeolium carmen ad Italos deduxisse modos). ${ }^{\prime}$ However, anyone familiar with even the rudiments of Latin literary history knows that Horace was not in fact the first to bring Aeolic verse forms to Latin: Catullus used Aeolic meter in at least four poems (the Sapphic C. 11 and 51, and glyconic/pherecratic C. 34 and 61 ), and he may have been preceded by Laevius or others. ${ }^{2}$ Horace was also not the first to mingle Greek and Latin elements in a more general way: virtually every major Roman poet back to the time of Livius Andronicus had done so in one fashion or another.

It is undeniable that Horace was thoroughly familiar with Catullus' work, and at numerous points alludes to it or imitates it, with particular notice given to the Aeolic $C .11,34$, and $51 .{ }^{3}$ Catullus was, in the previous generation, the poet who had assembled a varied polymetric collection not altogether unlike the Odes in its admixture of erotic, hymnic, occasional, literary critical, and satirical themes. ${ }^{4}$ Why then does Horace never mention or directly acknowledge Catullus in the Odes? Horace does not hesitate to address prominent contemporaries such as Vergil or Tibullus and to acknowledge the importance of ear-

1 It is echoed in $C$. 1.26.10-12 and Epistle 1.19.21-34 (on which see below). The claim is also reflected in the metaphors of $C$. 1.20.1-3 and 1.32.3-5.

2 While there are no certain examples of Aeolic verse in Laevius, Laevius did write polymetra and was known for experimentation with new metrical forms, especially ionic/anacreontic verses; see the discussion of E. Courtney, The Fragmentary Latin Poets (Oxford 1993) 118-20.

3 Among previous studies of Catullus' influence on Horace, the most important are C. W. Mendell, "Catullan Echoes in the 'Odes' of Horace," CP 30 (1935) 289-301; P. Gilbert, "Catulle et Horace," Latomus 1 (1937) 88-93; J. Perguson, "Catullus and Horace." AJP 77 (1956) 1-18; D. Gagliardi, Orazio $e$ la tradizione neoterica (Naples 1971) 99-129; M. O. Lee, "Catullus in the Odes of Horace," Ramus 4 (1975) 33-48; A. Traina, Poeti latini (e neolatini): Note e saggi filologici (Bologna 1980) 253-75; A. Traglia, "Catullo e i poeti nuovi visti da Orazio," in Letterature comparate, problemi e metodo: Studi in onore di Ettore Paratore (Bologna 1981) II, 467-86. For a fuller bibliographical survey, see E. A. McDermott, "Greek and Roman Elements in Horace's Lyric Program," in ANRW 11.31.3 (Berlin 1981) 1654-57.

4 A substantial body of opinion holds that Catullus' libellus first took the form of a smaller or larger collection of the polymetric poems (Cat. 1-14, 150 , or $1-51$, probably not 1-60). See, among others, W. V. Clausen, "Catulli Veronensis Liber," CP 71 (1976) 37-41; M. B. Skinner, Catullus' Passer: The Arrangement of the Book of Polymetric Poems (Salem, N.H., 1981); T. K. Hubbard, "The Catullan Libellus," Philologus 127 (1983) 218-37, with a fuller bibliographical survey at 218-19, n.2. Mendell (above, n.3) 295 seems to engage in a semantic quibble when doubting that Catullus would have considered himself a "lyrist." He had a polymetric libellus, along with other separately published works (epithalamia, epyllia, elegies, epigrams), even as Horace had books consisting of different poetic genres. 
lier Roman predecessors such as Ennius. ${ }^{5}$ In the Satires he positions himself relative to the work of his immediate precursor Lucilius very explicitly and programmatically.

Some clarification of Catullus' simultaneous presence and absence in Horace's Odes may be provided by Harold Bloom's theory of agonistic competition between an emerging poet and his dominant precursor. ${ }^{6}$ Bloom evolved an elaborate system of "revisionary ratios," whereby poets creatively misread their model, simultaneously foregrounding and repressing the influence of their poetic father, with whom they are locked into a dialectical embrace-unto-death from which they can never fully emerge. While Bloom's approach was developed primarily to illuminate the emerging voice of post-Enlightenment poets, some elements of it are clearly applicable to classical poetry also, given the ancients' preoccupation with personalizing issues of literary tradition and doctrine.?

There was an unmistakable difference in persona and temperament between the passionate Catullus, an archetypal angry young man, and the middle-aged, detached, bemused Epicurean Horace. Syme of course saw the difference in terms of Horace's quietism and subservience to the regime, as opposed to Catullus" "free and passionate" individualism. ${ }^{8}$ Yet beneath the difference lay a fundamental sameness in aesthetic doctrine: both were Callimachean exponents of the Musa tenuis, practitioners of learned allusion and Alexandrian subtlety, adept at ironic reversal and the witty mot juste. ${ }^{9}$

Two passages from outside the Odes illuminate Horace's relationship to his lyric model. The only explicit mention of Catullus in Horace's work comes from a programmatic text before the Odes were even conceived, the final poem of Satires I:

5 It is now generally agreed that the Vergilius of $C .1 .3$ and 1.24 is indeed Vergil the poet (4.12 is more doubtful), and that the Albius of $C .1 .33$ is the poet Albius Tibullus. For Ennius, see $C$. 4.8.15-24.

- The most significant works include The Anxiety of Influence (New York 1973), A Map of Misreading (New York 1975), Poetry and Repression: Revisionism from Blake to Stevens (New Haven 1976), and Agon: Toward a Theory of Revisionism (New York 1982).

7 See T. K. Hubbard, The Pipes of Pan: Intertextuality and Literary Filiation in the Pastoral Tradition from Theocritus to Milton (Ann Arbor 1998) $11-13$.

${ }^{8}$ R. Syme, The Roman Revolution (Oxford 1939) 461: "Catullus, however, could not have been domesticated, tamely to chant the regeneration of high society, the reiterated nuptials of Julia or the frugal virtues of upstarts enriched by the Civil Wars. His books would have been burned in the Forum, with the greatest concourse and applause of the Roman People."

9 On Horace's general affinity with the neoterics, see L. Alfonsi, Poetae novi: Storia di un movimento poetico (Como 1945) 112-16; Gagliardi (above, n.3) 60-98; and N. B. Crowther, "Horace, Catullus, and Alexandrianism," Mnemosyne ser. 4, 31 (1978) 33-44. Traglia (above, n.3) 472 sees the difference not as one of poetic doctrine, but of persona: Catullus is the poeta doctus, Horace the poeta sapiens. On Horace's Callimacheanism, see the essential works of F. Wehrli, "Horaz und Kallimachos," $M H$ 1 (1944) 69-76: W. Wimmel, Kallimachos in Rom: Die Nachfolge seines apologetischen Dichtens in der Augusteerzeit (Wiesbaden 1960); H. Mette, "Mensa tenuis und genus tenue bei Horaz," $M H 18$ (1961) 136-39; J. V. Cody, Horace and Callimachean Aesthetics (Brussels 1976). 
ridiculum acri

fortius et melius magnas plerumque secat res. illi, scripta quibus comoedia prisca viris est, hoc stabant, hoc sunt imitandi; quos neque pulcher Hermogenes umquam legit, neque simius iste nil praeter Calvum et doctus cantare Catullum.

(Sat. 1.10.14-19)

The mirthful is stronger than the sharp and mostly settles great affairs better. Those men who were poets of Old Comedy succeeded in this and are to be imitated in this, whom neither pretty Hermogenes has ever read nor that ape who has been trained to sing nothing except Calvus and Catullus. ${ }^{10}$

The principal intent of this satire is to defend Horace's literary theories against the supporters of Lucilius, including Hermogenes and perhaps Demetrius (whom Porphyrio, ad Serm. 1.10.18, identifies as the simius)." Horace begins by extolling the virtues of brevity $(1.10 .9-10)$ and variety (1.10.11-15), particularly defined as alternating between a serious and humorous style, the latter sometimes being the more effective way to register a point, as the writers of Old Comedy knew. Demetrius is criticized for knowing nothing of these older texts, being familiar only with the last generation of trendy neoteric poets. That Catullus and Calvus were enormously popular and influential during this period is well attested by the numerous references to their work in Vergil's Eclogues, ${ }^{12}$ as well as the Catullan character of the Catalepton. Some critics have argued that Catullus and Calvus are not themselves objects of Horace's criticism here so much as their mediocre imitators. ${ }^{13}$ But the vocabulary of Sat. 1.10.1719 does suggest parody of neoteric style: pulcher and doctus serve Catullus as emblematic code words for cultivation in personal appearance and poetic practice, respectively, and cantare may be meant to echo Cicero's derisive appellation of the neoterics as cantores Euphorionis. ${ }^{14}$

${ }_{10}$ This and all subsequent translations are mine.

$"$ B. L. Ullman, "Horace, Catullus, and Tigellius," $C P 10$ (1915) 294-95, and J. Perret, Horace, tr. B. Humez (New York 1964) 44, are not altogether convincing in regarding these defenders of Lucilius as critics of Catullus and Calvus. On the doctrines of this circle, see also G. L. Hendrickson, "Horace and Valerius Cato," $C P 11$ (1916) 249-69.

12 Servius (ad Buc. 6.47) identifies Calvus' Io as the source of the line. For other possible Calvan allusions, see R. F. Thomas, "Theocritus, Calvus, and Eclogue 6," CP 74 (1979) 337-39, and "Cinna, Calvus, and the Ciris," $C Q$ n.s., 31 (1981) 371-74. For the influence of Catullus on the Eclogues, see Hubbard (above, n.7) 75, n.58, 78-85, 91-92. Propertius 2.34.87-88 refers to Lesbia as now more famous than Helen.

13 See, for example, E. K. Rand, "Catullus and the Augustans," HSCP 17 (1906) 29: "In satirizing a Methodist of Preraphaelite leanings-I hope I am not straining analogy-whose acquaintance with English poetry was limited to two of his recently sanctioned hymns, the Crossing of the Bar and the Recessional, we should not thereby intend disrespect to Tennyson or Kipling."

14 For pulcher, see Cat. 61.84, 64.28, 68.105, 86.5 (of women), 61.191 and 79.1-3 (of men). For doctus, see Cat. 1.7, 35.17, 65.2 (all in programmatic contexts). Cicero refers to the "new poets" as cantores Euphorionis at Tusc. 3.19.45; see Alfonsi (above, n.9) 114; Crowther (above, n.9) 34-35, n.15; Traglia (above, n.3) 469. P. Lejay, Oeuvres d'Horace: Satires (Paris 1911) 256-59, regards Cicero as a major theoretical influence on this satire in other respects. 
Horace's manner of referring to Calvus and Catullus, while not exactly polemical, does seek to minimize the significance of the two poets who were all the rage among his contemporaries. The virtues of brevity and variety in tone which Horace advocates in the lines leading up to this reference are indeed characteristic of Calvus and Catullus; Horace in effect adopts their program. ${ }^{15}$ But at the same time that he echoes neoteric poetics, he suppresses and trivializes the importance of these predecessors, instead drawing attention to Attic Old Comedy (relatively little read in Rome) as the original source for such practices. For Horace, it is essential to know the older models as well as the more recent ones: this doctrine later becomes fundamental for the Odes, and is precisely the basis for his finding fault with Hermogenes and Demetrius.

The other programmatic text which illuminates Horace's theory of imitation and frames his achievement in the Odes comes from the period immediately after the publication of Odes 1-3. Epistle 1.19 inveighs against slavish imitators (Ep. 1.19 .19 o imitatores, servum pecus). Like Demetrius and Hermogenes in Sat. 1.10, they adopt a single model and imitate even its faults, aping the austere appearance of Cato without achieving his virtue or trying to appear as urbanus and disertus as the sharp-tongued Timagenes. Horace contrasts his own freedom in adapting models with the derivative unoriginality of these "groupies":

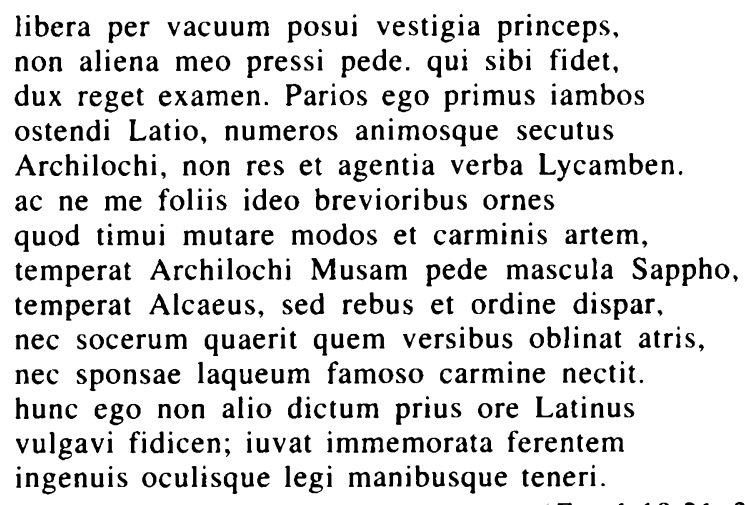

(Ep. 1.19.21-34)

I first placed free footsteps on an untrod path; I have pressed with my foot tracks not belonging to another. Who trusts in himself will rule the swarm as a leader. I first showed Parian iambs to Latium, having followed the meter and spirit of Archilochus, but not the subject matter and words which hounded Lycambes. But lest you deck me with a shorter laurel crown because I was afraid to change the meter and type of song, manly Sappho tempers the Archilochian Muse with her foot; Alcaeus tempers it, though different in subject matter and stanza. Neither does he seek

is The passage immediately following (Sat. 1.10.20-35) criticizes Lucilius for using too many Greek words in his verse. Here too Horace's restraint is in line with Catullus' limited usage of Grecisms and avoidance of actual Greek. 
a father-in-law to smear with black verses, nor does he tie the noose for his betrothed with his ill-famed song. A Latin poet, I have popularized this lyrist, not previously sung by another's mouth; it delights me to bring forward the previously unspoken, to be read by noble eyes and held by noble hands.

In the Epodes he adopted the meter and spirit of Archilochus, but changed the subject matter. In creatively revising Archilochus this way, Horace did much as Sappho and Alcaeus, who were of course his principal inspiration in Odes 1-3. Moreover, Horace seems to position Sappho and Alcaeus as counterbalancing influences which "temper" the harshness and astringency of Archilochus. As in Sat. 1.10, a poet's originality should consist in knowing how to combine selectively a variety of models, including overlooked poets from the earliest strands of Greek tradition (Old Comedy in Sat. 1.10, the archaic lyric poets in Epp. 1.19, especially Alcaeus, whom no Roman poet prior to Horace imitated).

Horace's technique of combining newer with older models is well illustrated by the short $C$. 1.32:

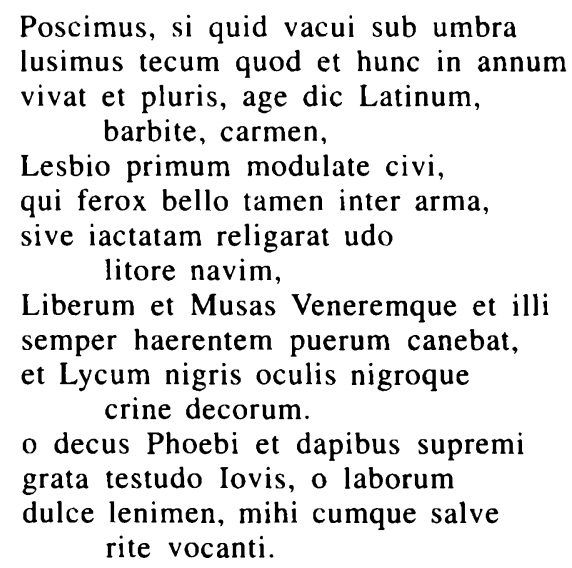

We ask you, if we have played with you beneath the shade anything idle which should live for this year and a few more, come, O lyre, strike up a Latin song, lyre first played by the Lesbian citizen who was fierce either in war and arms or when he had moored his battered ship on the wet shore, who nevertheless sang Liber and the Muses and Venus and the boy who always clings to her side, and who sang Lycus, comely with his dark eyes and dark hair. $\mathrm{O}$ glory of Phoebus and tortoise-shell pleasing to the feasts of highest Jove, $\mathrm{O}$ sweet solace of labors, hail!-as I duly invoke you by whatever name.

In addition to the obvious appeal to Alcaeus in the second and third stanzas, Mendell long ago noted that this poem contains a number of salient references to Catullus' vocabulary and phraseology. ${ }^{16}$ Most

16 Mendell (above, n.3) 299-300. 
significant among these are the echoes of two programmatic poems in the Catullan collection: vacui . . lusimus $(C$. 1.32.1-2) rather clearly evokes otiosi . . lusimus, similarly placed in the first two lines of Catullus 50, describing his literary collaboration with Calvus. ${ }^{17}$ Equally noteworthy is the relative clause wishing that the song may live eternally, expressed with mock-modest self-deprecation: Horace's quod et hunc in annum / vivat et pluris (C. 1.32.2-3) seems to one-up Catullus' quod . . . I plus uno maneat perenne saeclo (Cat. 1.9-10) in the contest of polite understatement. It may be significant that Horace chooses to allude here to the end of Catullus' prologue poem and to the beginning of what was very possibly the epilogue of the polymetra. ${ }^{18}$ After these two clear Catullan allusions in the first stanza, Lesbio as the initial word of the second stanza cannot fail to conjure up associations with the name of Catullus' beloved; all the more is the reader's surprise when it turns out to identify an altogether different poet. The unassuming, almost casual colloquialism of Catullus 1 is also picked up in Horace's indefinite internal accusative quid (C. 1.32.1; cf. Cat. 1.8 quidquid hoc libelli) and the odd use of the indefinite cumque at the end of the poem $\left(C .1 .32 .15-16\right.$; cf. Cat. 1.9 qualecumque).$^{19}$

Not previously noticed, but perhaps significant, is that Horace also plays on the next poem in the Catullan collection, addressed to Lesbia's pet sparrow. Horace's lusimus tecum $(C$. 1.32.2) is parallel to Catullus' tecum ludere (Cat. 2.9), even as his calling the lyre a laborum / dulce lenimen near the end of the poem ( $C$. 1.32.14-15) echoes Catullus" wish that the sparrow "lighten the sad cares of my mind" (Cat. 2.10 tristis animi levare curas) at the conclusion of his poem. But more important is the fact that both poems employ a mock-hymnal style to address their non-divine objects: in Catullus we see the vocative followed by appositives and relative clauses, and a final concluding wish, ${ }^{20}$ while the hymnal quality of Horace's poem is defined by the initial hypomnesis (= "reminder of past services"), repeated vocatives associating the lyre with other gods in the fourth stanza, and the final formula which makes it clear that Horace regards every-

17 The first stanza of the poem may also nod toward the opening of another neoteric-inspired collection of poems-Vergil's Eclogues. Ecl. I.1-5 situates Tityrus reclining in leisure beneath the shade of a tree (lentus in umbra), playing his favorite musical instrument.

${ }^{18}$ For C. 50 as epilogue, see Clausen (above, n.4) 40.

19 Mendell (above, n.3) 300, also notes that age dic (C. 1.32.3) echoes dic agedum in Cat. 67.7. The cumque has occasioned much controversy among commentators, and many emendations have been proposed. For a sound discussion, see E. Fraenkel, Horace (Oxford 1957) 170-71, who connects the phrase

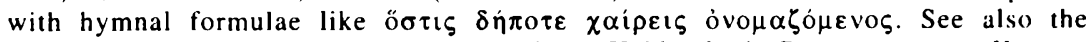
extensive notes of R. G. M. Nisbet and M. Hubbard, A Commentary on Horace: Odes, Book $I$ (Oxford 1970) 365-67, who resort to the strategy of emendation, and of A. W. J. Holleman, "Some Notes on Horace, Odes 1.32.15-16," AC 41 (1972) 228-32, who defends cumque.

20 The hymnal quality of Cat. 2 has been expounded in detail by J. D. Bishop, "Catullus 2 and Its Hellenistic Antecedents," $C P$ 61 (1966) 158-65. Its accompanying twin, Cat. 3 (lugete, o Veneres Cupidinesque), obviously takes the form of a mock dirge. 
thing up to this point as a prayer (C. 1.32.15-16 mihi cumque salve / rite vocanti). ${ }^{21}$ The passer poems of Catullus themselves came to be emblematic for his collection as a whole, which Martial (4.14.13-14) referred to simply as the Passer. It may be that they were already in Horace's time perceived as programmatic, perhaps in virtue of their position next to the Prologue.

It is worth speculating why Horace chose to concentrate these allusions to Catullus' programmatic poetry, especially his Prologue (Cat. 1), in a non-prologic poem. Hendrickson actually supposed, on different grounds, that $C .1 .32$ might be the original prologue to an earlier collection of odes. ${ }^{22}$ This theory can be rejected, since $C .1 .32$ lacks the dedicatee necessary to make it a true parallel to Catullus' first poem. ${ }^{23}$ It is noteworthy that neither $C .1 .1$ nor 3.30 , framing the Horatian collection, betrays any Catullan reminiscence; indeed, nothing could be further from the Catullan posture of self-deprecatory understatement than the boldly self-proclaiming rhetoric of these poems. To have squared off with Catullus in his own prologue poem would be to acknowledge Catullus as too important; by relegating his Catullan reference to a subordinate position in the collection, Catullus' influence as a precursor is minimized at the same time it is recognized.

This ambiguous acknowledgment and suppression of Catullus is also manifest in Horace's turn to Alcaeus as his explicit poetic model in the second and third stanzas. Whereas Catullus is never named or otherwise personalized in this poem, Alcaeus is very clearly evoked as the Lesbius civis, and his various poetic themes are reviewed in a meaningful sequence, moving from public concerns in the second stanza (civil war, the ship of state, both relevant to Alcaeus as Lesbius civis), to private matters in the third (the symposium and love). It is interesting that Horace employs a hendiadys familiar from Catullus $(C$. 1.32.9 Musas Veneremque; cf. Cat. 68.10 muneraque et Musarum . . . et Veneris $)^{24}$ to designate Alcaeus' love poetry. Horace's technique here is precisely to mingle Greek and Roman elements, taking his metrical and thematic inspiration from archaic poets like Alcaeus, his phrasing and ironic technique from Roman predecessors like Catullus and pos-

21 On the hymnal form of $C$. 1.32, see Fraenkel (above, n.19) 168-73; Nisbet and Hubbard (above, n.19) 359-60; H. P. Syndikus, Die Lyrik des Horaz (Darmstadt 1972-73) I, 287-88; D. West, Horace, Odes I: Carpe Diem (Oxford 1995) 152-57. They do not use the term "hypomnesis" of the si quid.. . clause, but that is clearly what it is: see G. Appel, De Romanorum precationibus (Giessen 1909) 149-52; K. Keyssner, Gottesvorstellung und Lebensauffassung im griechischen Hymnus (Stuttgart 1932) 134; H. Meyer, Hymnische Stilelemente in der frühgriechischen Dichtung (Cologne 1933) 4-5.

22 G. L. Hendrickson, "The First Publication of Horace's Odes," CP 26 (1931) 2-3.

${ }^{23}$ C. 2.1, contrasting Pollio's historical writing to the poet's lighter strains, comes closer to Cat. 1 in this regard, inasmuch as that poem compares/contrasts Nepos' history with the poet's libellus.

24 For a survey of scholarly discussion of this phrase, see B. R. Dollar, "Genre Crossing and Intertextuality in Catullus 68" (M.A. report, Univ. of Texas, 1997) 9-18. 
sibly Vergil: it is in this sense that the Greek $\beta \alpha \rho \rho \imath \tau o v$, once tuned by Alcaeus, is asked to sing Latinum carmen (C. 1.32.3-5).

Horace also reaches beyond Catullus to valorize Greek models in C. 1.22 , the famous poem Integer vitae:

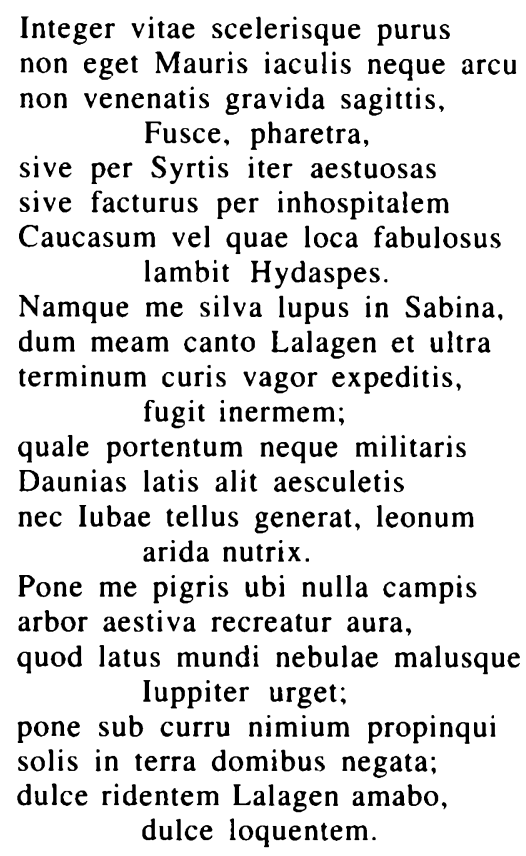

The man sound in life and pure of crime needs not Moorish spears nor a bow and quiver heavy with poisoned arrows, O Fuscus, whether he is to make his way through the burning Syrtes or through the inhospitable Caucasus or the places which the fabled Hydaspes washes. For in the Sabine wood a wolf fled from me, unarmed, while I was singing my Lalage and wandering past my boundary with all cares set aside; such a portent neither martial Daunias begets in its broad oak forests nor the land of Juba, dry nurse of lions. Put me in frozen plains where no tree is revived by a summer breeze, a part of the world that clouds and an ill-tempered Jove presses down; put me beneath the chariot of the too close Sun in a land denied to houses; I shall love my Lalage, sweetly laughing, sweetly speaking.

It has long been recognized that this Sapphic poem alludes to Catullus' two efforts in the Sapphic meter: ${ }^{25}$ the geographical catalogue of the

25 See Mendell (above, n.3) 297; Ferguson (above, n.3) 9-10; Nisbet and Hubbard (above, n.19) 265; Lee (above, n.3) 39-40; Traina (above, n.3) 25859; F. Cupaiuolo, "Contribution à l'interprétation d'Horace lyrique, l'ode I,22 (Integer Vitae)," in S. Krésic, ed., Contemporary Literary Hermeneutics and Interpretation of Classical Texts (Ottawa 1981) 171-72. However, S. Commager, The Odes of Horace: A Critical Study (New Haven 1962) 132-35, sees the vows of Septimius in Cat. 45.1-7 as the primary model; this view follows H. J. 
second stanza, articulated in the form of a sive . . . sive . . construction describing the wild extremes of the earth, echoes a similar catalogue in the second and third stanzas of Cat. 11, also presented in a disjunctive sive ... seu . . . sive . . . sive . . . sequence. Horace adopts from Catullus as well the tone of exaggerated mock solemnity leading up to an absurd conclusion: Catullus' "friends" Furius and Aurelius, prepared to journey to the ends of the earth on his behalf, are here asked to go across town and deliver a message to Lesbia (Cat. 11.1316). ${ }^{26}$ At the end of $C$. 1.22, Horace alludes to Catullus' other Sapphic poem, Cat. 51, coming toward the end of Catullus' polymetra: ${ }^{27}$ dulce ridentem $(C .1 .22 .23)$ is an exact quotation of Cat. 51.5, in the same metrical position. However, Horace corrects Catullus' translation of Sappho by adding in the next line dulce loquentem (C. 1.22.24), which

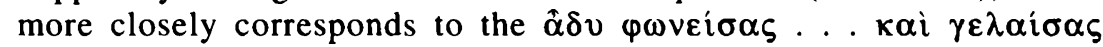

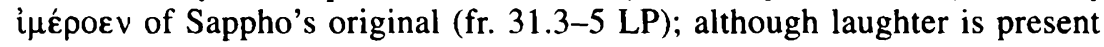
in Sappho, the word which most closely corresponds with the Latin

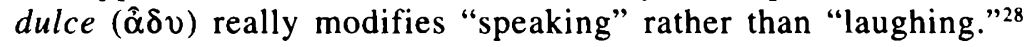

C. 1.22 engages with Catullus in another more implicit way that has not been recognized. The theme of a wild animal fleeing a weak and defenseless musician who is under some form of divine protection is well attested in a tradition of Hellenistic poetry concerning

Munro, Criticisms and Elucidations of Catullus (Cambridge 1878) 237-38. But the lengthier geographical catalogue of Cat. $11.5-12$ seems to be the more likely source of C. 1.22.5-8. A. W. J. Holleman, "Horace's Lalage (Ode 1,22) and Tibullus' Delia," Latomus 28 (1969) 575-82, constructively suggests that the Catullan references (to which he adds $C$. 1.22.11 curis expeditis = Cat. 31.7 solutis curis) are part of a larger program in this poem parodying the conventions of contemporary love elegy, which was the Augustan heir to Catullus and the neoterics; cf. Lee (above, n.2) 39-43.

26 D. Armstrong, "Some Recent Perspectives on Horace," Phoenix 51 (1997) 394, sees a similar deflationary intent in Horace's other allusion to the Catullan catalogue in $C$. 2.6.1-4, which turns out ultimately to be a poem about real estate: "every echo of Catullus he makes is systematically put into a less exciting or less erotic shape or context." On this poem's allusion to Catullus, see also J. A. Trelogan, "From Amor to Amicitia: A Catullan Theme in the Odes of Horace" (M.A. report, Univ. of Texas, 1996) 24-36.

${ }^{27}$ For Cat. 51 (rather than Cat. 50) as the epilogue to the polymetra, see C. P. Segal, "The Order of Catullus, Poems 2-11," Latomus 27 (1968) 307, n.1, and Skinner (above, n.4) 85-92. Even if Horace read the poems of Catullus in the format we possess today, Cat. 11 comes about one-sixth of the way through the polymetra (reflected by its imitation in the second stanza of $C$. 1.22, out of six), and Cat. 51 comes close to the end (reflected by its imitation in the last stanza of $C .1 .22$ ).

${ }^{28}$ On the correction, see Ferguson (above, n.3) 7-8; Lee (above, n.3) 40; Traina (above, n.3) 262. For this technique of correction as one Catullus himself used (in regard to Ennius' translation of Euripides), see Cat. 64.1-7, as explained by R. F. Thomas, "Catullus and the Polemics of Poetic Reference (Poem 64.1-18)," AJP 103 (1982) 148, 155. For the phenomenon as a more general practice, see the same author's "Virgil's Georgics and the Art of Reference," HSCP 90 (1986) 185-89. 
Atys, the eunuch devotee of Cybele, and a lion. ${ }^{29}$ Sat. 1.9.68-70 suggests that Fuscus, the addressee of this poem, may have even had a special interest in Eastern religions. ${ }^{30}$ Several epigrams from the Garland of Meleager relate the story of the beggar priest who frightens the lion away by rattling his tambourine, but most important is that of the Alexandrian-era Dioscorides:

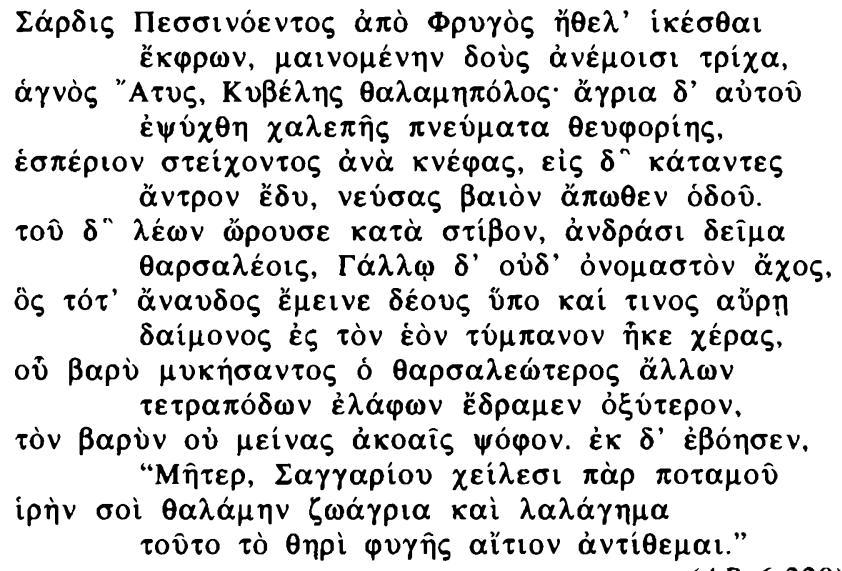

Holy Atys, the attendant of Cybele, wished to reach Sardis from Phrygian Pessinus, frenzied and giving his crazed hair to the winds. The wild panting of his difficult enthusiasm became cool when darkness fell that evening, and he entered into a descending cave, parting a bit from the road. Then a lion leaped onto his path, fearful to brave men and an unnameable pain to the gallus, who then froze speechless in his fear and by the inspiration of some god put his hands on his noisy tambourine. When it roared deeply, the lion, bolder than other beasts, ran away faster than deer, not bearing to hear the deep noise, and Atys shouted forth: "O Mother, by the banks of the River Sangarias, I dedicate to you as a thank-offering for my life the sacred chest and this sound, cause of the beast's flight."

29 This story is the subject of several epigrams ( $A P$ 6.217-220, 237), on the date of which, see A. S. F. Gow, "The Gallus and the Lion," JHS 80 (1960) 88-93. It is part of a broader Hellenistic tradition of poetry concerning galloi, the eunuch priests of the Great Mother (cf. AP 6.51, 6.94, 6.234, 11.195); the tradition may go back to the elegy of Hermesianax mentioned by Pausanias 7.17.9-10 (= fr. 8 Powell). Hephaestion, Enchir. 12.3, quotes a Greek fragment in galliambic meter, and $U$. von Wilamowitz-Moellendorff, "Die Galliamben des Kallimachos und Catullus," Hermes 14 (1879) 194-201 (revised in Hellenistische Dichtung in der Zeit des Kallimachos [Berlin 1924] II, 291-95), even speculated about a Callimachean original behind Catullus' Attis poem. On the tradition generally, see also K. M. W. Shipton, "The 'Attis' of Catullus," $C Q$ n.s., 37 (1987) 444-46.

${ }^{30}$ I owe this suggestion to one of $C W$ 's anonymous referees. 
Particularly suggestive for the interpretation of $C .1 .22$ is the last word of v. $15 \lambda \alpha \lambda \alpha \gamma \eta \mu \alpha$, cognate to the Greek $\lambda \alpha \lambda \alpha \gamma \eta$, both of which usually mean "sound." 31 Like the gallus, Horace frightens the predatory animal away by making a "sound," which is what it means to "sing Lalage" (C. 1.22.10 canto Lalagen). Lalage should not be seen as a real woman at all, but as a metonymy for Horace's own poetry, especially in the form of love poetry. ${ }^{32}$

Of course the most famous adaptation of the Atys tradition in Roman poetry, which was doubtless thoroughly familiar to both Horace and his audience, was Catullus' galliambic Attis (Cat. 63). ${ }^{33}$ However, Catullus inverts the usual story of the goddess-protected priest frightening away the lion by instead presenting the angry goddess setting one of her lions against Attis and frightening the rebellious priest back into her sacred grove (Cat. 63.76-90). By going back to the original Greek story and apparently ignoring Catullus' more familiar and recent poem, in a context where reminiscence of Catullus has already been awakened, Horace effectively corrects the Catullan narrative in much the same way that dulce loquentem corrects Catullus' translation of Sappho. In both cases, Horace moves through Catullus to privilege the authority of the Greek original.

The catchy phrase integer vitae scelerisque purus at the beginning of $C .1 .22$ may well be intended as an implicit contrast of Horace's own persona, still capable of love and sensual enjoyment, with that of the castrated eunuch, who is far from integer. ${ }^{34}$ Here we may see the tacit influence of Catullus' poem also, with its emphasis on the violent act of castration and Attis' day-after feelings of repentance: his central lament (Cat. 63.50-73) is for his lost vita. By declaring himself integer vitae in contrast to the emasculated Attis, is Horace implying something about the difference between his own poetic per-

31 For an extended discussion of the word's meaning here, with full bibliography, see H. White, Essays in Hellenistic Poetry (Amsterdam 1980) 69-78. G. Pasquali, Orazio lirico (Florence 1920) 476, speculates about a lost Hellenistic poem with a girl named Lalage, but this text seems much more likely to be the source of the name.

32 The general parallel between these epigrams and $C$. 1.22 has been noted by two earlier scholars: H. W. Prescott, "Horace's Integer Vitae," CP 20 (1925) 276-77, and C. Josserand, "Dum meam canto Lalagen . . . , AC 4 (1935) 363. But neither scholar wished to see them as a direct source, and as a result they have received little attention from subsequent criticism; however, see Nisbet and Hubbard (above, n.19) 262, and K. N. MacFarlane, "'Integer Vitae': A Wolf by the Ears," CJ 77 (1981) 25-26. Prescott noted the similarity between $\lambda \alpha \lambda \dot{\alpha} \gamma \eta \mu \alpha$ and the name Lalage, but dismissed it as purely coincidental. It is taken more seriously by G. Davis, "Carmina/lambi: The Literary-Generic Dimension of Horace's Integer Vitae (C. I,22)," QUCC n.s., 27 (1987) 67-68, who also favors "Lalage" as a generic metonymy for love poetry, programmatically preferred to the "wolf" of iambic poetry (= the Epodes).

${ }^{33}$ For the direct influence of these epigrams on Catullus, see E. Courtney, "Three Poems of Catullus," BICS 32 (1985) 88-91, and Shipton (above, n.28) 444-45.

${ }^{34}$ For integer in the basic sense of "unwounded" and "whole of body," see $T L L$, s.v. integer II, A, I, a, a. 
sona, secure in its Epicurean tranquility, and that of the passionate, self-destructive Catullus, enslaved to a man-consuming virago ${ }^{35}$ About this we can only speculate.

Horace's technique of inverting or reversing Catullan models is well paralleled in other poems. It has been noted that Europa's lament in C. 3.27 is a comic version of the tragic lament of Catullus' Ariadne (Cat. 64.132-201) ${ }^{36}$ C. 4.12.13-28 inverts and corrects the dinner invitation of Cat. 13: Horace's poem asks the guest to bring some fragrant nard (good etiquette), whereas Catullus asked his guest to bring everything but the perfume, which was to be the host's sole contribution (bad etiquette). ${ }^{37}$ Fraenkel and others have observed that the first two stanzas of $C$. 2.16 seem intended as a positive defense of Epicurean otium against the condemnation of otium in the final stanza of Cat. 51: both passages are in Sapphic meter and are structured around a triple anaphora of the word at the beginning of lines. ${ }^{38}$ Critics have also seen the platitude-filled love duet of Septimius and Acme in Cat. 45 as the source for Horace's dialogue with Lydia in C. 3.9. ${ }^{39}$ But instead of the saccharine sentimentality of the naive young lovers in

${ }^{35}$ For Attis as an autoallegory of the poet's own persona, see P. W. Harkins, "Autoallegory in Catullus 63 and 64," TAPA 90 (1959) 105-11; M. C. J. Putnam, "Patterns of Personality and Imagery in the Poetry of Catullus (dissertation summary)," HSCP 65 (1961) 371; T. Oksala, "Catulls Attis-Ballade: Über den Stil der Dichtung und ihr Verhältnis zur Persönlichkeit des Dichters," Arctos 3 (1962) 210-12; T. J. Sienkewicz, "Catullus-Another Attis?," CB 67 (1981) 4243. See M. B. Skinner, "Ego Mulier: The Construction of Male Sexuality in Catullus," Helios 20 (1993) 124, n.22, for further bibliography. Skinner regards Attis as a symbol not so much of Catullus himself as of the whole generation of politically "castrated" males at the end of the Roman Republic.

36 Mendell (above, n.3) 289-94 notes that Horace's version does not emphasize the usual details of the Europa myth, as seen in Moschus or Ovid, but instead gives us a tableau obviously modeled on Catullus-a princess abandoned on the shore, lamenting her betrayal of father and family. Mendell also observes numerous correspondences of phraseology and vocabulary between the two poems. See, further, Gagliardi (above, n.3) 115-16; T. Berres, "Zur Europaode des Horaz (c. 3,27)," Hermes 102 (1974) 85-86; and $M$. Lowrie, Horace's Narrative Odes (Oxford 1997) 308-11, who notes that both poems problematize the relation between frame and inset narrative. On the quality of comic spectacle in Horace's myth, see J. Griffin, Latin Poets and Roman Life (London 1985) 106-7.

${ }^{37}$ See Ferguson (above, n.3) 11-12; Gagliardi (above, n.3) 123; Syndikus (above, n.21) II, 403-5; M. C. J. Putnam, Artifices of Eternity: Horace's Fourth Book of Odes (Ithaca 1986) 206-7. Gilbert (above, n.3) 88-92 observes that one of Horace's other odes to Vergil $(C$. 1.24) also plays with a Catullan model (Cat. 96), suggesting that Catullus' value as a paradigm was a topic of discussion between the two poets.

38 Fraenkel (above, n.19) 211-14; Mendell (above, n.3) 297; Ferguson (above, n.3) 8; Lee (above, n.3) 35; R. G. M. Nisbet and M. Hubbard, $A$ Commentary on Horace: Odes, Book II (Oxford 1978) 257. Traglia (above, n.3) 479 denies any polemical or ironic intent to Horace's allusion; cf. Syndikus (above, n.21) I, 444.

39 See Gilbert (above, n.3) 90-91; Ferguson (above, n.3) 12-13; R. M. Nielsen, "Catullus 45 and Horace Odes 3.9: The Glass House," Ramus 6 (1977) 132-38; M. C. J. Putnam, Essays on Latin Lyric, Elegy, and Epic (Princeton 1982) 117-25; Trelogan (above, n.26) 9-23. 
Catullus, pledging eternal fidelity against a background of ill omen (Amor's sneeze on the left), Horace displays the wizened cynicism of a middle-aged roué and courtesan, who know their vows of fidelity to be insincere and hackneyed topoi: Horace and Lydia are a deconstructed version of Septimius and Acme thirty years later.

Such reversals were standard practice for Catullus himself, as for instance in attributing to himself as a male the feminine role of Sappho. ${ }^{40}$ We should therefore not see Horace's play with Catullan models as a mark of deep-seated hostility or even as a systematic polemic, but as a poetic agonism which was altogether within the spirit of Hellenistic and neoteric practice. Imitation of technique is the sincerest form of flattery, even when that imitation itself takes the form of rebellion against the authority of the one imitated.

It is always in the nature of one poetic generation to measure itself against another, and of individual poets to set themselves in competition with an earlier poet who tried doing something similar. Horace's techniques of inverting Catullan texts or alluding to them only to bypass them in favor of earlier Greek models must be interpreted as strategies of self-positioning. He saw Catullus as an interesting and significant model, but one who only partially and imperfectly fulfilled the lyric aspirations Horace set for himself. ${ }^{41}$

University of Texas at Austin CW 94.1 (2000)
THOMAS K. HUBBARD

tkh@mail.utexas.edu

40 This reversal is seen both in his translation of Sappho, fr. 31 LP (of two women) in Cat. 51, and in his application to himself of the image of the flower trampled underfoot in Cat. 11.22-24 (an image of violated virginity in Sappho, fr. 105c LP). For a multifaceted study of Catullus techniques in playing with earlier models, focusing on Cat. 64.1-18, see Thomas (1982, above, n.28) 144-64.

41 The author acknowledges a debt to David Armstrong and the two anonymous referees of $C W$ for many constructive suggestions. Special recognition is owed to my student Ned Tuck (Latin teacher at the Hockaday School) for inspiring much of my discussion of $C$. 1.22. None of these individuals are to be held responsible for my conclusions or errors. 